\title{
PERAN KETERLIBATAN HIJABERS DI MEDIA SOSIAL TERHADAP PERILAKU BELANJA ONLINE BUSANA MUSLIM
}

\author{
Vita Briliana $^{1}$, Tita Deitiana ${ }^{2}$, Nurwanti Mursito ${ }^{3}$ \\ ${ }^{1}$ Jurusan Manajemen, Trisakti School of Management, Jakarta \\ Email:vita@stietrisakti.ac.id \\ 2 Jurusan Manajemen, Trisakti School of Management, Jakarta \\ Email: tita@stietrisakti.ac.id \\ ${ }^{3}$ Jurusan Manajemen, Trisakti School of Management, Jakarta \\ Email:nurwanti29@yahoo.com
}

\begin{abstract}
ABSTRAK
Tujuan penelitian untuk mengetahui mengidentifikasi keterlibatan hijabers di social media dikarenakan motivasi, peluang, kemampuan dan suka terhadap perilaku belanja online. Populasi dalam penelitian ini adalah pengguna Facebook dalam rangka bertransaksi belanja online khususnya busana muslim. Metode pengambilan sampel menggunakan purposive sampling dengan jumlah 316 responden. Teknik analisis data menggunakan analisis SEM (Smart-PLS). Hasil penelitian menyatakan bahwa motivasi, kemampuan dan suka mempunyai pengaruh positif terhadap keterlibatan media sosial dalam belanja online dikalangan hijabers. Sementara peluang tidak memiliki pengaruh terhadap keterlibatan di media sosial.
\end{abstract}

Kata Kunci: Ability, Facebook, Motivation, Opportunity, Social Media

ABSTRACT

The purpose of the study was to identify the effects of motivation, opportunity, ability, and likes on social media involvement for online shopping. The population in this study is the Facebook users in order to transact online shopping, especially Muslim fashion. Sampling method in this research is purposive sampling with 316 respondents. Data analysis techniques use SEM (Smart-PLS) analysis. The results stated that motivation, ability, and likes have a positive influence on involvement in social media through online shopping among hijabsta. While opportunities have no influence on involvement in social media.

Keywords: Ability, Facebook, Motivation, Opportunity, Social Media

\section{PENDAHULUAN}

\section{Latar Belakang}

Perkembangan semakin pesat di bidang teknologi internet berperan penting pada semua bidang seperti jasa retail seiring meningkatnya kebutuhan dan perubahan gaya hidup konsumen. Laporan Profil Pengguna Internet Indonesia tahun 2018 yang dipublikasikan Asosiasi Perusahaan Jasa Internet Indonesia (APJII, 2019) menginformasikan pengguna internet di Indonesia pada tahun 2018 mencapai 171.17 juta orang, dan sekitar 64.8 persen nya yang terhubung dengan internet, dari total populasi sebanyak 264 juta jiwa penduduk Indonesia. Didukung oleh publikasi online dari Kompas.com menyatakan bahwa jumlah pengguna media sosial mencapai 150 juta jiwa, Facebook memiliki 130 Juta pengguna aktif bulanan di Indonesia (Kompas, 2019). Berdasarkan penelitian Briliana (2017) ruang lingkup Jakarta menunjukkan selama beberapa dekade, pengecer dan peneliti telah menyadari bahwa berbelanja bukan hanya masalah memperoleh produk yang nyata, tetapi juga tentang pengalaman berbelanja dan smartphone semakin sering digunakan 24/7 untuk mengakses media sosial, seperti Facebook, Instagram dan sebagainya. Konsumen menggunakan teknologi internet untuk mencari kebutuhannya, seperti mencari referensi tentang mode pakaian Muslim dan saling berbagi informasi tentang pengalaman berbelanja maupun untuk menyelesaikan transaksi pembelian dengan mudah. Sedangkan bagi pengecer, di forum online atau komunitas di mana mereka 
menjadi anggota memanfaatkan dengan menampilkan beberapa sampel pakaian mereka yang terbaru sehingga lebih menghemat biaya dibandingkan menyiapkan dan memajangnya dioutlet.

Berdasarkan data yang dikutip dari Indonesia.go.id ditahun 2019, jumlah penduduk muslim hingga 87,2 persen atau sekitar 207 juta jiwa (https://www.indonesia.go.od/profil/agama, 2019). Indonesia, negara dengan jumlah Muslim terbesar di dunia, menjadikannya pasar potensial untuk berbagai industry untuk pasar kelas menengah muslim yang tumbuh luar biasa, seperti perbankan syariah, haji/umrah, fesyen, kosmetik dan lainnya (Briliana dan Mursito, 2017a). Agama Islam menyuratkan bahwa pemakaian hijab bagi wanita muslim adalah suatu kewajiban, sesuai yang tertulis dalam Al-Qur'an surat An-Nur ayat ke 31 dan Al-Ahzab ayat 59. Berdasarkan laporan berita online yang dirilis oleh swa online yang dipublikasikan (swaonline, 2017), bahwa wanita muslim di Indonesia yang berhijab semakin terdorong untuk lebih memperhatikan mode fashion dengan terbentuknya Hijabers Community (komunitas blogger) ditahun 2010 sebagai gejala atau fenomena ramainya fesyen muncul ketika konsumen ingin mendapat pengakuan sebagai suatu pribadi. Pada dasarnya karena mereka ingin membentuk atau menetapkan identitas personalnya sebagai wanita muslim dan kemudian bersatu dengan kelompok yang sama akan ketertarikannya, persepsinya akan aturan berbusana bagi wanita muslim. Istilah Hijaber dalam penelitian ini merujuk pada remaja putri muslim di era masa kini yang tampil modis mengikuti perkembangan trend fesyen hijab yang elegant dan memenuhi persyaratan pakaian muslimah yang menutup aurat sesuai dengan ajaran Islam.

Teknologi internet tidak hanya mengubah cara kita berkomunikasi one on one atau juga manyto-many (MacIaran, Catterall, 2002), tetapi juga cara konsumen melakukan proses keputusan pembelian. Ketika membuat keputusan pembelian, sudah umum bagi konsumen untuk merujuk pada keterlibatan di media sosial. Pelanggan online sering mencari informasi produk sebelum membuat keputusan pembelian dan menggunakan informasi lain sebagai dasar yang mempengaruhi pembelian mereka (Chen dan Xie, 2008). Dampak media sosial selama proses keputusan pembelian konsumen melalui jejaring sosial, khususnya Facebook, ditemukan sebagai platform berbagi informasi yang paling sesuai pada awal pembelian konsumen keputusan karena banyak konsumen mengandalkan rekomendasi sosial dan banyak konsumen menggunakan ulasan dan peringkat Facebook ("suka"/ "like") sebagai sarana untuk mencari rekomendasi, saran rekan, dan menemukan informasi produk (Fauser et al.2011). Munculnya mode busana muslim telah memberikan kesempatan untuk mendefinisikan kembali simbol Muslim. Mode busana muslim sesuai dengan munculnya hijaber, yakni wanita muslim yang berpakaian modis dan/atau desain pakaian modis, sambil berorientasi pada apa yang diperintahkan oleh agama Islam. Pengusaha busana muslim menargetkan wanita yang mengenakan busana muslim dengan menjual keperluan busana muslim secara online dan memposting video tutorial hijab, tutorial berbusana sesuai syariat muslim, lokakarya, dan program lain yang berkaitan dengan hijab mode seperti yang dilakukan oleh beberapa UKM melalui jejaring sosial seperti Facebook, Instagram dan sebagainya.

Kesenjangan penelitian diidentifikasi dalam literatur tentang keterlibatan di media sosial. Banyak penelitian berfokus pada hasil (Gruen et al.2007; Fauser et al.2011; Leung dan Bai.2013; Briliana et al.2015; Briliana dan Mursito.2017b), tetapi kurang mengidentifikasi fokus pada bagaimana keterlibatan di media sosial dimulai. Oleh karena itu, penelitian yang dilakukan lebih mendalam di bidang ini diperlukan. Maka berdasarkan penelitian sebelumnya yang menyatakan bahwa dampak media sosial dalam belanja online (Fauser et al.2011; Briliana dan Mursito.2017b), dan faktor-faktor yang mempengaruhi keterlibatan menggunakan media sosial (Briliana et al.2015) maka dalam penelitian ini memperdalam dengan menambahkan 
variabel liking (menyukai) yang tidak dibahas dalam penelitian sebelumnya. Dengan demikian tujuan penelitian ini untuk menjawab pertanyaan apakah motivation (motivasi), opportunity (peluang), ability (kemampuan), liking (menyukai), memberikan pengaruh pada keterlibatan media sosial khususnya melalui Facebook terhadap online buying behavior (perilaku belanja online) dikalangan hijabers.

\section{Tinjauan Pustaka}

Theory Reasoned Action (TRA) berakar dalam penelitian Ajzen and Fishbein (1980). Teori ini membahas upaya yang dilakukan untuk memahami penyebab perilaku orang-orang itu sendiri dan perilaku orang lain. Sementara penerapannya mungkin berbeda, mereka semua menyelidiki ke area umum tentang bagaimana konsumen memproses informasi pasar untuk membuat keputusan dalam pembelian. Teori atribusi berfokus pada bagaimana pengamat sosial menggunakan informasi untuk sampai pada penjelasan kausal untuk perilaku tertentu. Untuk anggota forum komunitas online, fokusnya adalah pada persepsi, yang melibatkan diskusi tentang berbagai subjek yang mencakup gaya, pola, warna, desainer, dan merek produk (Briliana dan Mursito, 2017b)

\section{Motivation}

Motivasi umumnya dipandang sebagai kekuatan yang mengarahkan individu ke arah tujuan tertentu (Leung dan Bai, 2013). Menurut Gruen et al.(2007) menyatakan bahwa pelanggan yang termotivasi akan memiliki energi, siap, dan bersedia terlibat dalam kegiatan dalam menciptakan nilai. Berdasarkan penelitian Briliana dan Mursito (2017) bahwa motivasi mengacu pada keinginan konsumen untuk melakukan pembelian online karena manfaat yang dirasakan menggunakan media sosial (misalnya, Facebook), dan itu secara positif mempengaruhi niat mereka. Disimpulkan motivasi adalah suatu kemampuan yang mendorong seseorang untuk memenuhi kebutuhan akan produk atau jasa yang harus dipenuhi. Motivasi seseorang menggunakan media sosial yakni Facebook sebagai kegiatan pemenuhan kebutuhan akan informasi dan berbagi pengalaman berbelanja seperti cara pemesanan secara online, system pembayaran yang aman dan mudah serta dapat dilakukan dimanapun dan kapanpun. Maka hipotesis:

$\mathrm{H}_{1}$ : Motivasi berpengaruh positif terhadap keterlibatan di media sosial khususnya Facebook pada kalangan hijabers.

\section{Opportunity}

Menurut Leung dan Bai (2013) bahwa peluang mengacu pada faktor situasional yang dapat meningkatkan atau menghambat pemrosesan informasi. Peluang mencerminkan sejauh mana situasi kondusif untuk mencapai hasil yang diinginkan (Gruen et al., 2006, 2007). Berdasarkan penelitian Briliana dan Mursito (2017) bahwa jika informasi tidak tersedia, peluang itu juga tidak ada, diasumsikan ketersediaan anggota Facebook untuk mengakses Facebook tanpa batasan praktis atau teoritis (downtime halaman web, tidak cukup waktu untuk menavigasi, atau pembatasan yang dikenakan oleh organisasi). Disimpulkan peluang yang dirasakan pelanggan untuk menggunakan media sosial (misalnya, Facebook) secara positif dapat mempengaruhi niat mereka untuk berbelanja online. Sebuah peluang yang muncul untuk mendapatkan keuntungan bagi para konsumen untuk mencoba tanpa menguji barang itu sendiri dengan mencari informasi sebanyak-banyaknya di media sosial tentang kegunaan, maupun kerugian jika ada sebelum melakukan pembelian, sehingga membantu kemudahan saat memutuskan untuk belanja online sesuai kebutuhan. Maka hipotesis yang diajukan :

$\mathrm{H}_{2}$ : Peluang berpengaruh positif terhadap keterlibatan di media sosial khususnya Facebook pada kalangan hijabers. 


\begin{abstract}
Ability
Dalam penelitian Leung dan Bai (2013) kemampuan didefinisikan sebagai sejauh mana wisatawan memiliki sumber daya yang diperlukan (misalnya, pengetahuan, kecerdasan, uang) untuk membuat hasil yang terjadi. Gruen et al., (2007) mendefinisikan kemampuan sebagai keterampilan atau kemahiran pelanggan untuk terlibat dalam pertukaran informasi. Tanpa keterampilan atau kemampuan yang diperlukan, bahkan individu yang termotivasi tidak mungkin akan terlibat di kegiatan media sosial dengan pelanggan lain. Kemampuan merupakan kumpulan keterampilan dan kompetensi anggota Facebook yang membuat mereka mampu berkomunikasi dengan anggota lain. Selama tahap perkembangan sikap inilah pengecer online dapat mempengaruhi kecenderungan pembeli untuk belanja online (Briliana dan Mursito,2017). Disimpulkan kemampuan adalah suatu bakat/keterampilan yang dimiliki seseorang konsumen untuk memilih suatu produk yang diinginkan dengan cara mudah yakni browsing dengan menggunakan smartphone untuk mengakses media sosial khususnya Facebook. Maka hipotesis yang diajukan :

$\mathrm{H}_{3}$ : Kemampuan berpengaruh positif terhadap keterlibatan di media sosial khususnya Facebook pada kalangan hijabers.
\end{abstract}

\title{
Liking
}

Menurut Duffett (2017) mendefinisikan menyukai suatu merek dengan memiliki kecenderungan yang menguntungkan untuk itu (respon sikap afektif); ditunjukkan dengan menampilkan preferensi terhadap sutau merek dalam hubungannya dengan orang lain dengan memiliki sikap positif terhadapnya (respon sikap afektif). Penelitian dari Kabadayi dan Price (2014) dengan 269 responden Milenium di Amerika Serikat mengungkapkan berbagai jenis individu dan interaksi komunikasi massa di Facebook dan kepribadian dipengaruhi tanggapan afektif dalam bentuk rasa suka (liking). Apabila konsumen merasa kegiatannya dalam hal berbagi pengalaman berbelanja, atau pengalaman menggunakan busana muslim yang nyaman dan modis maka umumnya wanita muslim senang untuk mempostingnya di Facebook (Briliana dan Mursito, 2017). Disimpulkan menyukai adalah ungkapan rasa suka akan suatu pengalaman berbelanja dengan menggunakan Facebook sebagai media untuk berbelanja online. Maka hipotesis yang diajukan :

$\mathrm{H}_{4}$ : Kesukaan berpengaruh positif terhadap keterlibatan di media sosial khususnya Facebook pada kalangan hijabers.

\section{Involvement in Social Media}

Jejaring sosial, khususnya komunitas merek di Facebook ditemukan sebagai platform berbagi informasi yang paling sesuai pada awal keputusan pembelian konsumen karena banyak konsumen mengandalkan rekomendasi sosial dan banyak konsumen menggunakan kisah di Facebook, ulasan, dan peringkat ("suka") sebagai sarana untuk mencari rekomendasi, saran rekan dan menemukan informasi produk (Leung dan Bai, 2013). Menurut Briliana dan Mursito (2017) bahwa keterlibatan dimedia sosial merupakan aktivitas individu yang berminat dengan intensitas, termotivasi, dan ketekunan untuk berbagi informasi dan pengalaman. Di penelitian ini di simpulkan keterlibatan di media sosial merupakan langkah awal mencari informasi atau berbagi pengalaman dalam mengkonsumsi barang dalam rangka mempermudah pertimbangan dalam memutuskan belanja online.

$\mathrm{H}_{5}$ : Keterlibatan di media sosial khususnya Facebook berpengaruh positif terhadap perilaku belanja online pada kalangan hijabers. 


\section{Online Buying Behavior}

Duffett (2017) mengemukakan bahwa pengguna internet yang paling aktif menunjukkan kecenderungan terbesar untuk menggunakan konten komersial yang tersedia secara online untuk membantu keputusan pembelian. Aplikasi media sosial dan jejaring sosial memungkinkan pemasaran viral yang efektif di mana komunikasi merek dalam bentuk pesan pemasaran menyebar cepat dan luas di jaringan yang berbeda dengan asumsi bahwa pesan tersebut cukup memikat. Efektivitas pemasaran viral didasarkan pada faktor yang sama seperti Word of mouth, yang dipercaya ditempatkan pada pengirim pesan dan pengalaman yang diperoleh dari viral marketing. Untuk sebagian besar produk dan merek yang menarik, pengguna membuat komunitas online (MacIaran \& Catteral 2002). Pada dasarnya proses pembelian online berbeda tahapannya dibandingkan proses pembelian dating ke toko atau retail secara fisik. Kekhasan dari proses membeli melalui media internet dimulai ketika konsumen menggunakan internet dan mencari informasi yang berkaitan dengan barang atau jasa yang mereka butuhkan, baik dari sisi variasi model design, ukuran warna maupun harga dan sebagainya. Dalam penelitian ini disimpulkan perilaku belanja online adalah proses pembelian produk melalui jejaring media social yakni Facebook, dari mencari informasi hingga bertransaksi.

\section{METODE PENELITIAN}

\section{Populasi dan Sampel Penelitian}

Yang dimaksud dengan populasi dipenelitian ini merupakan netizen yang rutin menggunakan media sosial khususnya Facebook dan berpenghasilan serta sudah pernah melakukan belanja online busana muslim minimal 2 kali selama jangka waktu tiga bulan terakhir agar dapat mencapai tujuan penelitian.

\section{Metode Pengambilan Sampel}

Sekitar 350 kuesioner dibagikan dengan metode purposive sampling. Survey dilakukan dengan google survey dan disampaikan melalui direct message di Facebook maupun whatsapp message. Untuk mendukung justifikasi kebiasaan memanfaatan teknologi maka pemilihan responden yang berkriteria memiliki motivasi, kemampuan, dan peluang terhubung dengan internet untuk belanja online (Briliana et al., 2015). Namun, hanya 316 formulir survei akhir yang dapat digunakan. Jumlah ini berkontribusi dengan memberikan tingkat tanggapan 90 persen, yang dapat dianggap memuaskan untuk analisis pemodelan persamaan struktural (SEM). Penggunaan SEM sebagai bentuk menginterpretasikan data dengan menilai kecocokan keseluruhan model dan pengujian model struktural gabungan (Chin, 1998; Gefen et al., 2000). Pada dasarnya SEM terdiri dari dua pendekatan yaitu, berbasis komponen (PLS-SEM) dan covarians (CB-SEM) (Hair et al., 2017). PLS-SEM dan CB-SEM memiliki perbedaan dalam hal asumsi statistik yang mendasari mereka dan sifat dari statistik fit. CB-SEM sesuai ketika tujuan penelitian adalah untuk menguji atau mengkonfirmasi teori, sedangkan PLS-SEM adalah metode alternatif yang digunakan ketika asumsi distribusi CB-SEM tidak dapat dipenuhi dan ketika tujuan penelitian adalah untuk memprediksi menggunakan teori yang kurang dikembangkan (Hair et al.,2017). Sehingga, PLS-SEM adalah metode yang dianggap cocok untuk penelitian ini karena orientasi prediksi dari teori yang kurang berkembang.

Tabel 1. Variabel dan Pengukuran

\begin{tabular}{|c|c|c|}
\hline Variabel & Item pertanyaan & $\begin{array}{l}\text { Diadaptasi } \\
\text { dari sumber }\end{array}$ \\
\hline Motivasi (M) & $\begin{array}{l}\text { M1. Di media sosial seperti Facebook bisa mempelajari tentang hal-hal } \\
\text { yang bermanfaat } \\
\text { M2. Di media sosial seperti Facebook merupakan cara yang bagus } \\
\text { untuk mendapatkan informasi yang saya inginkan }\end{array}$ & \\
\hline
\end{tabular}




\begin{tabular}{|c|c|c|}
\hline & $\begin{array}{l}\text { M3. Di media sosial seperti Facebook, saya bisa bicara dengan orang } \\
\text { lain sesuai topik yang menarik }\end{array}$ & \\
\hline Peluang (O) & $\begin{array}{l}\text { O1.Saya memiliki sedikit waktu luang untuk mengalokasikan selama } \\
\text { bekerja } \\
\text { O2. Bila koneksi internet saya lebih cepat, saya akan lebih sering } \\
\text { menggunakan media sosial seperti Facebook } \\
\text { O3.Waktu ekstra yang saya miliki di tempat kerja terbatas }\end{array}$ & $\begin{array}{l}\text { Leung dan Bai } \\
\text { (2013) }\end{array}$ \\
\hline $\begin{array}{c}\text { Kemampuan } \\
\text { (A) }\end{array}$ & $\begin{array}{l}\text { A1. Saya memiliki kemampuan untuk menggunakan social media } \\
\text { seperti Facebook. } \\
\text { A2. Saya memiliki sarana untuk membagikan pengetahuan ini di social } \\
\text { media seperti Facebook. } \\
\text { A3. Saya mampu berbagi pengetahuan di social media seperti } \\
\text { Facebook. }\end{array}$ & \\
\hline Menyukai (L) & $\begin{array}{l}\text { L1. Beriklan di media sosial seperti Facebook telah membuat saya } \\
\text { lebih menyukai merek } \\
\text { L2. Iklan di media sosial seperti Facebook menambah kenikmatan } \\
\text { menggunakan media sosial } \\
\text { L3. Iklan di media sosial seperti Facebook menjengkelkan dan } \\
\text { mengganggu } \\
\text { L4. Iklan di media sosial seperti Facebook menghibur dan } \\
\text { menyenangkan } \\
\text { L5. Media sosial seperti Facebook memiliki pengaruh positif pada saya } \\
\text { menyukai produk yang diiklankan } \\
\text { L6. Saya memiliki perasaan positif terhadap merek yang diiklankan di } \\
\text { media sosial seperti Facebook } \\
\text { L7. Ada terlalu sedikit iklan di Facebook } \\
\text { L8. Media sosial seperti Facebook mempengaruhi saya untuk } \\
\text { menyukai merek yang diiklankan }\end{array}$ & Duffett (2017) \\
\hline $\begin{array}{l}\text { Keterlibatan } \\
\text { media sosial } \\
\quad \text { (IS) }\end{array}$ & $\begin{array}{l}\text { IS1.Sangat penting untuk terlibat di media sosial seperti Facebook } \\
\text { IS2.Sangat berharga untuk terlibat di media sosial seperti Facebook } \\
\text { IS3.Berarti banyak bagi saya untuk terlibat di media sosial seperti } \\
\text { Facebook }\end{array}$ & $\begin{array}{l}\text { Leung dan Bai } \\
\text { (2013) }\end{array}$ \\
\hline $\begin{array}{l}\text { Perilaku } \\
\text { Belanja online } \\
\quad \text { (OB) }\end{array}$ & $\begin{array}{l}\text { OB4.Saya membeli produk yang diiklankan di media sosial seperti } \\
\text { Facebook } \\
\text { OB5.Saya menggunakan banyak produk yang merupakan fitur di } \\
\text { media sosial seperti Facebook } \\
\text { OB6.Iklan di media sosial seperti Facebook mempengaruhi perilaku } \\
\text { pembelian saya secara positif } \\
\text { OB7.Iklan di media sosial seperti Facebook menyenangkan } \\
\text { OB8.Saya membeli produk yang dipromosikan di media sosial seperti } \\
\text { Facebook }\end{array}$ & Duffett (2017) \\
\hline
\end{tabular}

\section{Teknik Analisis Data}

Structural equation modelling dengan program PLS, digunakan sebagai alat ukur.

1. Untuk mengetahui apakah setiap indicator dapat mengukur dimensi setiap variable dengan uji validitas dengan menggunakan analisa outer loading factor, cross loading factor, serta AVE. Sementara reliabilitas diuji dengan analisa cronbach alpha dan composite reliability.

2. Tahap selanjutnya model yang diestimasi memenuhi kriteria Outer Model, maka dilakukan pengujian model structural (Inner model). Nilai R-Square pada konstruk. Menjelaskan seberapa besar suatu konstruk dapat dijelaskan melalui konstruk yang berhubungan.

3. Path Coefficient menjelaskan semua pengujian variabel antar variabel adalah signifikan. Sehingga dapat disimpulkan bahwa semua hipotesis dapat diterima atau ditolak. Bootstrap diterapkan untuk memvalidasi hasil dari hipotesis, dengan 5000 sampel bootstrap yang dipilih untuk two-tailed test berdasarkan nilai $t$-value 1,96 (tingkat signifikansi $=5 \%$ ), dan 2,57 (tingkat signifikansi level =1\%) (Hair et al., 2017). 


\section{HASIL DAN PEMBAHASAN Profil Responden}

Menurut profil responden, penelitian menemukan sebagian besar $(70,6 \%)$ berada di kelompok usia 19-24 tahun, karyawan $(59,8 \%)$, dan sebagian besar $(73,4 \%)$ mengakui bahwa mereka pengguna Facebook lebih dari 2 tahun.

Terdapat 2 model dalam PLS Path Modeling yaitu outer model dan inner model. Kriteria uji dilakukan pada kedua model tersebut

\section{Evaluasi Measurement (Outer) Model}

Tujuan outer model menganalisa atau mengidentifikasi bagaimana setiap indikator berhubungan dengan variabel latennya. Adapun uji yang dilakukan pada outer model sesuai dengan tabel 2 :

Tabel 2 . Hasil analisa measurement model dan convergent validity

Sumber: Hasil Pengolahan PLS

\begin{tabular}{|c|c|c|c|c|c|c|}
\hline Variabel & Items & $\begin{array}{c}\text { Outer } \\
\text { Loading }\end{array}$ & AVE & $\begin{array}{l}\text { Composite } \\
\text { Reliability }\end{array}$ & $\begin{array}{c}\text { Cronbach } \\
\text { Alpha }\end{array}$ & $\begin{array}{c}\mathrm{R} \\
\text { Square }\end{array}$ \\
\hline \multirow{3}{*}{$\begin{array}{l}\text { Motivasi } \\
\text { (M) }\end{array}$} & M1 & 0.896 & 0.779 & 0.914 & 0.858 & \\
\hline & M2 & 0.886 & & & & \\
\hline & M3 & 0.866 & & & & \\
\hline \multirow{3}{*}{$\begin{array}{l}\text { Peluang } \\
\text { (O) }\end{array}$} & $\mathrm{O} 1$ & 0.827 & 0.755 & 0.902 & 0.837 & \\
\hline & $\mathrm{O} 2$ & 0.897 & & & & \\
\hline & $\mathrm{O} 3$ & 0.881 & & & & \\
\hline \multirow{3}{*}{$\begin{array}{c}\text { Kemampuan } \\
\text { (A) }\end{array}$} & A1 & 0.820 & 0.771 & 0.910 & 0.850 & \\
\hline & A2 & 0.914 & & & & \\
\hline & A3 & 0.897 & & & & \\
\hline \multirow{8}{*}{$\begin{array}{l}\text { Menyukai } \\
\text { (L) }\end{array}$} & S1 & 0.913 & 0.735 & 0.957 & 0.947 & \\
\hline & S2 & 0.901 & & & & \\
\hline & S3 & 0.916 & & & & \\
\hline & S4 & 0.820 & & & & \\
\hline & S5 & 0.711 & & & & \\
\hline & S6 & 0.896 & & & & \\
\hline & S7 & 0.821 & & & & \\
\hline & S8 & 0.859 & & & & \\
\hline Keterlibatan & IS1 & 0.850 & 0.784 & 0.916 & 0.862 & 0.823 \\
\hline \multirow{2}{*}{$\begin{array}{l}\text { Media sosial } \\
\text { (IS) }\end{array}$} & IS2 & 0.901 & & & & \\
\hline & IS3 & 0.904 & & & & \\
\hline \multirow{5}{*}{$\begin{array}{l}\text { Perilaku Belanja } \\
\text { Online } \\
\text { (OB) }\end{array}$} & OB4 & 0.640 & 0.628 & 0.893 & 0.849 & 0.629 \\
\hline & OB5 & 0.861 & & & & \\
\hline & OB6 & 0.782 & & & & \\
\hline & OB7 & 0.811 & & & & \\
\hline & OB8 & 0.847 & & & & \\
\hline
\end{tabular}

Berdasarkan tabel 2, menjelaskan bahwa nilai convergent validity yaitu nilai loading faktor pada variabel laten dengan indikatornya. Hasil menunjukkan nilai outer loading terendah 0.640 (perilaku belanja online) dan tertinggi 0.916 (menyukai), selain itu dikarenakan beberapa outer loading tidak memenuhi kriteria yakni > 0.5 maka di drop atau dihilangkan (Ghozali, 2016). Untuk mengukur validitas tiap indicator dengan menggunakan analisa Average Variance Extracted. Disimpulkan valid jika nilai AVE > 0.5 (Hair et al.2017). Hasil penelitian ini membuktikan bahwa semua nilai AVE diatas 0.5, maka disimpulkan valid. Hasil penelitian menunjukkan cronbach's alpha terendah sebesar 0.837 (peluang) dan yang tertinggi sebesar 0.947 (menyukai). Hal ini membuktikan bahwa semua konstruk adalah diatas 0.7, maka disimpulkan semua konstruk reliable. Sesuai dengan ketentuan dari Hair et al. (2017) bahwa variabel memenuhi reliabilitas jika memiliki cronbach's alpha $>0.7$. 


\section{Evaluasi Structural (Inner) Model}

Pengujian untuk mengevaluasi hubungan antar konstruk laten seperti hipotesis dalam penelitian, dengan output PLS diperoleh gambar sbb :

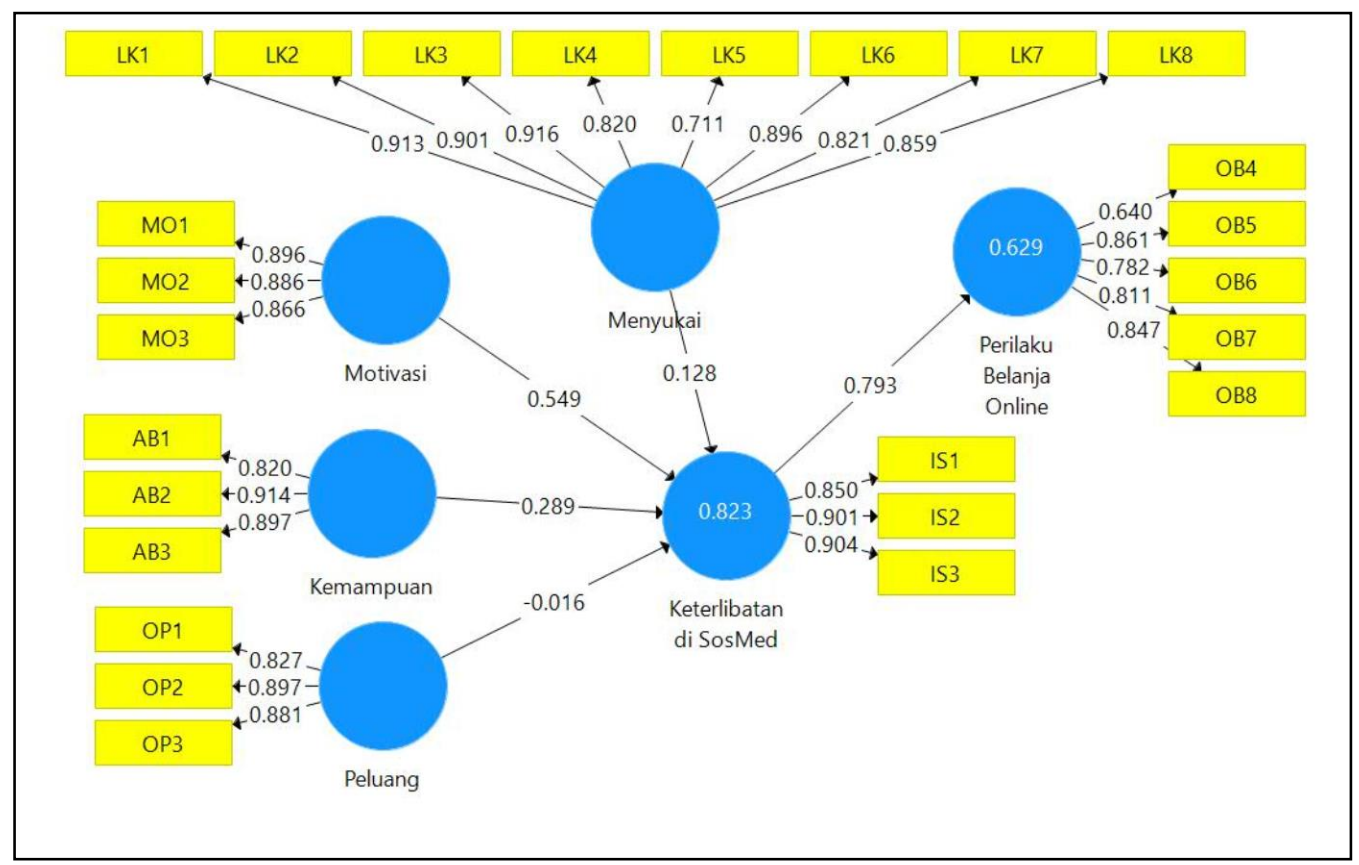

Gambar 1. Output Model Pengukuran PLS

Berdasarkan Gambar 1, menjelaskan bahwa pengujian goodness-fit-model berdasarkan output nilai R-Square sebesar 0.823, artinya pengaruh variabel motivation, opportunity, ability dan liking terhadap keterlibatan menggunakan media sosial (Y1) memberi nilai sebesar 0.823 yang dapat di interpretasikan bahwa variabel konstruk keterlibatan menggunakan media sosial dapat dijelaskan oleh variabel motivation, opportunity, ability dan liking sebesar 82,3 persen. Sedangkan sisanya 17.7 persen dijelaskan oleh variabel lain diluar yang diteliti. Selain itu variabel keterlibatan menggunakan media sosial mempengaruhi perilaku konsumen hijaber untuk belanja online dengan ditunjukkan nilai R-Square sebesar 0.629. Dalam penelitian ini di interpretasikan bahwa variabel konstruk perilaku belanja online dapat dijelaskan oleh variabel keterlibatan menggunakan media sosial sebesar 62,9 persen. Sedangkan sisanya 37.1 persen dijelaskan oleh variabel lain diluar yang diteliti.

\section{Pengujian Hipotesis}

Analisa hipotesis penelitian berdasarkan t-statistics sebagai berikut:

Tabel 3 Hasil Uji Hipotesa

\begin{tabular}{|c|c|c|c|c|c|c|}
\hline \multicolumn{3}{|c|}{ Path } & \multirow{2}{*}{$\begin{array}{c}\begin{array}{c}\text { Original } \\
\text { Sample } \\
(\mathbf{O})\end{array} \\
0.549\end{array}$} & \multirow{2}{*}{$\begin{array}{c}\begin{array}{c}\text { Standar } \\
\text { Deviation }\end{array} \\
0.551\end{array}$} & \multirow{2}{*}{$\begin{array}{r}\begin{array}{c}\text { T Statistic } \\
(|\mathbf{O} / \mathbf{S T E R R}|)\end{array} \\
4.399\end{array}$} & \multirow{2}{*}{$\begin{array}{r}\text { Keputusan } \\
\text { Diterima }\end{array}$} \\
\hline H1 & $M$ & IS & & & & \\
\hline $\mathrm{H} 2$ & $\mathrm{O}$ & IS & -0.016 & -0.008 & 0.239 & Ditolak \\
\hline H3 & A & IS & 0.289 & 0.066 & 4.399 & Diterima \\
\hline $\mathrm{H} 4$ & $\mathrm{~L}$ & IS & 0.128 & 0.108 & 5.188 & Diterima \\
\hline H5 & IS $\rightarrow$ & OB & 0.793 & 0.024 & 32.897 & Diterima \\
\hline
\end{tabular}




\section{Pembahasan}

\section{Motivasi (M) terhadap keterlibatan media sosial (IS)}

Motivasi berpengaruh signifikan terhadap keterlibatan media sosial. Pengaruh positif dapat dilihat dari nilai original sampel pada tabel uji hipotesis yang menunjukkan nilai positif $(0.549)$, dengan demikian dapat disimpulkan bahwa jika pengguna Facebook memiliki motivasi untuk terlibat di media sosial. Temuan ini sesuai dengan hasil penelitian (Gruen et al.2006; Leung dan Bai.2013; Briliana et al.2015). Motivasi mereka dalam mencari dan memilih hijab fashion termasuk kenyamanan, kesesuaian dengan kepribadian mereka, penerimaan rekan-rekan mereka, kepuasan pribadi dan cocok untuk acara-acara khusus.

\section{Peluang (O) terhadap keterlibatan media sosial (IS)}

Hasil temuan memperlihatkan peluang tidak berpengaruh signifikan terhadap keterlibatan media sosial. Tidak berpengaruh ini dapat dilihat dari nilai original sampel pada tabel uji hipotesis yang menunjukkan nilai negatif (-0.016), dengan demikian hijabers pengguna Facebook terdapat kepercayaan bahwa peluang tidak berpengaruh terhadap keterlibatan media sosial. Temuan penelitian konsisten dengan Gruen et al. (2006) menemukan bahwa peluang tidak memiliki pengaruh yang signifikan pada pertukaran informasi diantara wisatawan dalam konteks Internet.

\section{Kemampuan (A) terhadap keterlibatan media sosial (IS)}

Hasil penelitian menunjukkan bahwa kemampuan pengguna Facebook berpengaruh signifikan terhadap keterlibatan media sosial. Pengaruh positif juga dapat dilihat dari nilai original sampel pada tabel uji hipotesis yang menunjukkan nilai positif (0.289), dengan demikian jika terdapat kemampuan pengguna Facebook maka secara otomatis akan terlibat dalam menggunakan media sosial untuk platform berbagi informasi cara memilih busana muslim yang nyaman dikenakan, memposting tutorial cara menggunakan busana muslim yang tetap modis, merekomendasikan tempat penjualan dan sebagainya. Temuan ini kosisten dengan penelitian sebelumnya (Gruen et al.2006; Leung dan Bai.2013; Briliana et al.2015)

\section{Liking (L) terhadap keterlibatan media sosial (IS)}

Suka berpengaruh signifikan terhadap keterlibatan media sosial. Pengaruh positif juga dapat dilihat dari nilai original sampel pada tabel uji hipotesis yang menunjukkan nilai positif $(0.128)$, dengan demikian jika pengguna Facebook suka melibatkan diri dalam media sosial maka secara otomatis keterlibatan media sosial akan semakin terlihat dengan banyaknya postingan berbagi informasi atau review tentang model busana muslim yang sedang trend. Temuan ini kosisten dengan penelitian sebelumnya (Duffett 2017).

\section{Keterlibatan media sosial (IS) terhadap Belanja Online (OB)}

Hasil penelitian menunjukkan bahwa keterlibatan media sosial berpengaruh signifikan terhadap belanja online. Temuan ini kosisten dengan penelitian sebelumnya (Gruen et al.2006; Leung dan Bai.2013; Briliana et al.2015; Briliana dan Mursito, 2017; Duffett 2017). Pengaruh positif juga dapat dilihat dari nilai original sampel pada tabel uji hipotesis yang menunjukkan nilai positif (0.793), sehingga jika pengguna baju muslim rutin membuka media sosialnya yakni Facebook maka kemungkinan memperoleh informasi kaitannya dengan berbagi info tentang busana muslim seperti mode design terbaru, warna yang sedang trend, pengetahuan tentang bahan yang nyaman untuk wilayah tropis.

\section{KESIMPULAN DAN SARAN}

Tren fashion busana muslimah adalah busana wanita muslim terbaru yang dapat berubah-ubah di waktu-waktu tertentu dan sifatnya dinamis. Oleh karena itu motivasi dan memiliki kemampuan 
serta menyukai kegiatan dimedia sosial membuat pelanggan atau hijabers semakin terikat, berinteraksi secara intim, emosional terhadap suatu produk. Tanpa disadari social media merupakan salah satu penyebarluasan trend fashion, misalnya dari komunitas-komunitas hijabers yang menyajikan tutorial berpakaian Muslimah sesuai syariat Islam, mereview atau membahas tips-tips dan trend fashion terkini. Sehingga informasi melalui sosmed dalam hal ini Facebook akan cepat viral atau menyebar di masyarakat. Dampaknya penyedia busana (butik atau UKM bidang fashion Muslimah) secara online pun ikut memberikan peran dengan menyediakan berbagai busana yang mengikuti trend fashion terbaru sehingga mau tidak mau masyarakat akan mengikuti trend fashion yang sedang berkembang saat itu. Untuk itu diperlukan analisis dampak pemasaran media sosial pada keputusan pembelian memang diperlukan, karena pemasar dihadapkan dengan perubahan perilaku konsumen yang dipengaruhi oleh media sosial. Salah satu tantangan terbesar bagi pemasar adalah hilangnya kendali dan semakin pentingnya konten yang dihasilkan oleh konsumen dimedia sosial. Sejauh ini, media sosial pemasaran agak dicirikan oleh "trial and error" sementara tidak memiliki struktur dan perencanaan.

Ucapan Terima Kasih (Acknowledgement)

Para penulis berterima kasih kepada Sekolah Tinggi Ilmu ekonomi Trisakti, Jakarta Indonesia dan Kementerian Riset, Teknologi dan Pendidikan Tinggi Republik Indonesia yang telah memberikan dukungan keuangan untuk penelitian ini sebagai Hibah Penelitian Unggulan Perguruan Tinggi (PDUPT).

\section{REFERENSI}

Ajzen, I., \& Fishbein, M. (1980). Understanding attitudes and predicting social behavior. N.J: Prentice Hall.

Briliana Vita, NA Wahid, Y Fernando.(2015).The Effect of Motivation, Opportunity, Ability and Social Identity Towards Customer-to-Customer Online Know-How Exchange- Advanced Science Letters, Volume 21, Number 4, April 2015, pp. 819-822(4). https://doi.org/10.1166/asl.2015.5887

Briliana,Vita (2017). Identifying Antecedents and Outcomes of Brand Loyalty: a Case of Apparel Brands in Social Media. Paper presented to Proceedings of the Global Conference on Business and Economics Research (GCBER) (p319-326): Universiti Putra Malaysia, Malaysia.

Briliana,Vita and Nurwanti Mursito (2017a). Exploring antecedents and consequences of Indonesian Muslim youths' attitude towards halal cosmetic products: A case study in Jakarta.Asia Pacific Management Review, 22(4), 176-184. https://doi.org/10.1016/j.apmrv.2017.07.0122

Briliana, Vita \& Nurwanti Mursito (2017b), How Motivation, Ability, And Opportunity Can Drive Online Shopping Through Social Media, International Journal of Business, Economics And Law, Vol. 14, Issue 1 (December) 2017,Page 7- 12.

Chen, Y., Xie, J. (2008). Online consumer review: Word-of-mouth as a new element of marketing communication mix. Management Science, 54, 477-491.

Chin, W. (1998), "The partial least squares approach to structural equation modeling", in Marcoulides, G.A. (Ed.), Modern Methods for Business Research, Lawrence ErlbaumAssociates, Mahwah, NJ, pp. 295-336.

Fauser, S.G. Wiedenhofer, J. and Lorenz, M., (2011).Touchpoint social web": an explorative study about using the social web for influencing high involvement purchase decisions. Problems and Perspectives in Management, 9(1), pp.39-45.

Jumlah pengguna media sosial di Indonesia semakin bertambah., Kompas.com diunduh tanggal 23 April 2020 dipublikasikan sejak tgl 5 Februari 2019, tersedia di 
https://tekno.kompas.com/read/2019/02/05/11080097/facebook-jadi-medsos-palingdigemari-di-indonesia?

Gefen, D., Straub, D. and Boudreau, M.-C. (2000), "Structural equation modeling and regression: guidelines for research practice", Communications of the Association for Information Systems, Vol. 4 No. 7, pp. 2-77.

Gruen, T.W., Osmonbekov, T., Czaplewski, A.J., (2006). eWOM: the impact of customer-tocustomer online know-how exchange on customer value and loyalty. Journal of Business Research 59, 449e456.

Gruen, T. W., Osmonbekov, T., \& Czaplewski, A. J. (2007). Customer-to-customer exchange: Its MOA antecedents and its impact on value creation and loyalty. Journal of the Academy of Marketing Science, 35(4), 537-549.

Hair, Joseph F., G. Thomas M. Huls, Christian M. Ringle, \& Marko Sarstedt. (2017). A Primer On Partial Least Squares Structural Equation Modeling (PLS-SEM) 2nd edition. Los Angeles: SAGE Publications Inc.

Kabadayi, S. and Price, K. (2014).Consumer - brand engagement on Facebook: liking and commenting behaviors, Journal of Research in Interactive Marketing, Vol. 8 No. 3, pp. 203-223.

Maclaran, \& M. Catterall. (2002). Researching the social web: Marketing information from virtual communities, Marketing Intelligence \& Planning 20 (6), 319-326.

Pemerintah Republik Indonesia secara resmi hanya mengakui enam agama, yaitu Islam, Protestan, Katolik, Hindu, Buddha dan Konghucu. Indonesia diunduh tanggal 23 April 2020, tersedia di https://indonesia.go.id/profil/agama

Rodney Graeme Duffett, (2017). Influence of social media marketing communications on young consumers' attitudes, Young Consumers, Vol. 18 Issue: 1, pp.19-39, https://doi.org/10.1108/YC-07-2016-00622

Safko, L., \& Brake, D. K. (2009). The social media BibleeTactics. Tools \& for business

success. Hoboken, NJ: John Wiley \& Sons.

Survei APJII yang ditunggu-tunggu, penetrasi Internet Indonesia 2018 diunduh 4 Mei 2020 dipublikasikan pada bulan Mei 2019 tersedia di https://apjii.or.id/downfile/file/BULETINAPJIIEDISI40Mei2019.pdf

Wanita muslim di Indonesia yang berhijab semakin terdorong untuk lebih memperhatikan mode fashion dengan terbentuknya Hijabers Community diunduh 23 April 2018 diupdate 24 January 2017 tersedia di https://swa.co.id/youngster-inc/entrepreneur-youngsterinc/kamiidea-eksis-lewat-karya-fashion-nya

Xi Y. Leung \& Billy Bai (2013). How Motivation, Opportunity, and Ability Impact Travelers' Social Media Involvement and Revisit Intention, Journal of Travel \& Tourism Marketing, 30:1-2, 58-77, http://dx.doi.org/10.1080/10548408.2013.751211 